\section{Katkova N., Murashko I.}

\title{
THE FORMING OF SCENARIOS OF ENTERPRISE DEVELOPMENT ON THE BASIS OF FOUR-LEVEL INDICATOR OF SUSTAINABLE DEVELOPMENT
}

Об’єктом дослідження є методичний підхід до сиенарї̈ стійкого розвитку підприємства на базі чотиримірного показника рівня стійкого розвитку. Одним з найбільш проблемних питань є застосування такого методичного підходу до визначення рівня стійкого розвитку, який би дозволив сформувати відповідні сценарії у взаємодії із зовнішнім середовищем.

Для розробки комплексного показника, який би ураховував взаємний вплив підприємства та його екосистеми, під час дослідження було застосовано біономічний підхід, тобто підхід, притаманний вивченню біологічних систем. За основу показника оцінки рівня стійкого розвитку підприємства було використано показник екологічної ємності. Він характеризує граничну загрузку біологічного виду на середовище проживання або максимальний розмір популяціӥ виду, яку середа може безумовно стабільно підтримувати, забезпечувати їжею, укриттям, водою та іншими необхідними благами.

Удосконалено методичний підхід до формування сценаріїв розвитку підприємства шляхом розробки чотиримірного показника рівня стійкого розвитку, який надає можливості визначити здатність певних підсистем підприємства до розвитку, ураховуючи наявність ресурсів внутрішнього $і$ зовнішнього середовища. Розроблений показник складається з показників економічної, екологічної, соціальної та енергетичної ємності, характеристика яких наводиться у роботі. На підставі значення чотиримірного показника запропоновані сценарії стійкого розвитку підприємства, які являють собою комбінацію з підсистем, за якими ресурси є вичерпаними та у яких є запас ресурсів.

Для забезпечення збалансованого розвитку підприємства можливо здійснювати перерозподіл ресурсів між підсистемами, для чого за допомогою наведених сценаріїв стійкого розвитку визначаються відповідні заходи. Крім того, завдяки розробленій методиці забезпечується можливість визначення напрямів гармонійного співіснування підприємства із зовнішнім середовищем, що є головним принципом стійкого розвитку. У порівнянні з відомими підходами, запропонований чотиримірний показник рівня стійкого розвитку, а також визначені на його підставі сценарї, ураховують особливості існування підприємства у його екосистемі.

ключові слова: рівень стійкого розвитку підприємства, сценарії стійкого розвитку підприємства.

\section{Introduction}

In modern conditions of doing business and managing the achievement of enterprise sustainable development is an important condition for its long-term successful operation. At the same time, for a crisis-free development, an enterprise needs to ensure its harmonious coexistence with the external economic, environmental and social environment. The success of the enterprise's activities will depend on the mutual influence of the enterprise and the external environment, the production needs of the enterprise coincide with the capabilities of the external environment, and its tactical and strategic goals coincide with the available resources.

To identify ways to ensure sustainable development, an enterprise needs information on the availability of economic, environmental, social and energy resources, the correct redistribution of which will contribute to its effective development. Therefore, it is important to develop an indicator of the sustainable development of an enterprise that would take into account the mutual influence of the enterprise and the external environment. As well as determining the possibility of further development at the expense of external resources and the formation of scenarios for sustainable development of the enterprise.

\section{The object of research and its technological audit}

The object of research is a methodical approach to the scenarios of sustainable development of an enterprise based on the choice of a four-level indicator of sustainable development.

The main condition for the long-term crisis-free development of an enterprise is its attainment of harmonious economic, environmental, social and energy development in cooperation with the external environment.

Scenarios of sustainable development of the enterprise indicate the availability of resources of certain subsystems, as well as possible measures for the redistribution of resources.

To identify such scenarios, it is necessary to assess the level of sustainable development, taking into account the relationship of the enterprise with the ecosystem. To this end, an enterprise can apply a four-level indicator, built on the basis of indicators of economic, environmental, social 
and energy capacity, which allows to determine the possibility of further development of the enterprise, depending on the available resources of the external environment.

So, one of the biggest problem areas is the application of a methodical approach to determining the level of sustainable development, which would allow to form scenarios in interaction with the external environment.

\section{The aim and objectives of research}

The aim of research is improvement of the methodological approach to determining the level of sustainable development, which would allow the formation of scenarios in interaction with the external environment.

To achieve the aim of research, the following objectives are defined:

1. Build a four-level indicator of sustainable development of an enterprise, which would include indicators of economic, environmental, social and energy capacity.

2. Justify the development scenarios of the enterprise on the basis of a four-level indicator of sustainable development.

\section{Research of existing solutions of the problem}

Among the main directions of solving the problem of determining the level of sustainable development of an enterprise identified in the resources of world scientific periodicals, can be distinguished [1,2], but the developed approaches do not pay enough attention to harmonious coexistence of the enterprise with the external environment.

The authors of the work [3] show the effectiveness of implementing the practice of sustainable development in enterprises, however, there is an unresolved question of assessing the level of sustainable development.

The author's method of evaluating technical and economic indicators in implementation of the ecological and economic activity of an enterprise is given in [4]. But the issue of assessing the social and energy component of sustainable development is not resolved. And in [5], attention is focused on assessing the efficiency of using human capital in the context of sustainable development, also does not take into account all the components of sustainable development and does not provide a comprehensive assessment of the sustainable development of the enterprise.

In [6], an approach is developed to assess the achievement of enterprise results, namely: management and strategy, implementation of processes, sustainability indicators, indicators of innovation and human capital. Although it does not give an opportunity to determine the scenarios of sustainable development of the enterprise The importance of taking environmental factors into account when determining the development scenarios of an enterprise is given in studies [7, 8]. However, in these studies it is proposed to take into account only environmental factors, while social, energy and economic factors of the external environment are ignored. A similar approach can be traced in the works [9, 10]. However, the above approaches do not provide an opportunity to determine the level of sustainable development of the enterprise, taking into account environmental factors.

In [11], scenarios of sustainable development in the context of a shortage of a certain type of resources are investigated. This study examines only the possibility of reducing economic resources, and does not provide an opportunity to assess the level of sustainable development.

Thus, the results of the analysis allow to conclude that in the study of sustainable development, emphasis is placed on one or more subsystems of the enterprise, and the rest remain unheeded, as is the importance of the interaction of the enterprise with the external environment. This makes it impossible to obtain an assessment of the sustainable development of the enterprise and develop scenarios for its development.

In addition, studies on the formation of sustainable development scenarios are considered using a physical approach to assessing and predicting sustainable development, and in modern conditions it is not able to take into account the peculiarities of interaction of the enterprise and the external environment.

\section{Methods of research}

To achieve this aim, general scientific and special research methods are used:

- methods of analysis and synthesis - for a preliminary analysis with the aim of forming a problem and defining tasks for the formation of a four-level indicator of sustainable development and building on its basis the development scenarios of an enterprise;

- methods of analogy and modeling - for the construction of indicators of economic, environmental, social and energy capacity, and the four-level indicator of sustainable development;

- methods of decomposition and deduction - to identify measures in accordance with the scenarios of sustainable development of the enterprise.

\section{Research results}

An enterprise, as already noted in [11], can be viewed from the standpoint of bionomics, that is, as a living being that interacts with the environment throughout its existence. Therefore, in the study of problems of sustainable development of the enterprise, it is possible to use the approaches inherent in the study of biological systems.

An important indicator determining the viability of a particular species is the ecological capacity. This indicator characterizes the limiting load of a species on a habitat or the maximum size of a population of a species that the environment can unconditionally maintain, provide with food, shelter, water and other necessary benefits [12].

Ecological capacity is calculated by the formula:

$$
E_{i}=\frac{T_{i}}{\sum P_{i j}},
$$

where $E_{i}$ - the capacity for $i$-th constraints; $T_{i}-$ the value of the $i$-th resource; $P_{i j}-j$-th consumer's need for resources.

Comparing an enterprise with a living being, it can be determined that the resources of the external environment of an enterprise are also limited, and therefore, in case of their overspending, the ecosystem will resist the development and existence of the enterprise in order to reduce its excessive pressure. 
By analogy with the indicator of ecological capacity for living beings, it is possible to calculate the indicator of ecological capacity for each enterprise.

Environmental restrictions for the enterprise will be the standards for emissions of harmful substances into the air, water, and the like. Then the indicator of ecological capacity for the enterprise can be calculated by the formula:

$$
E_{c}=\sum \frac{T_{e i}}{P_{e i}}
$$

where $E_{c}$ - the ecological capacity; $T_{e i}$ - the value of the $i$-th environmental resource or the value of the $i$-th standard; $P_{i j}-j$-th enterprise's need for environmental resources or enterprise emissions.

It should be noted that when determining the possibility of sustainable development of an enterprise, in addition to environmental constraints, it is also necessary to take into account social, economic and energy constraints.

Thus, it is worth counting also indicators of the social, economic and energy capacity of the enterprise.

The economic capacity indicator is calculated by the formula:

$$
E_{e c}=\sum \frac{T_{e c i}}{P_{e c i}}
$$

where $E_{e c}$ - the economic capacity; $T_{e c i}$ - the standard value of the $i$-th economic indicator; $P_{e c i}-$ the actual value of the $i$-th economic indicator of the enterprise.

Economic restrictions will be the normative values of indicators of economic development, the list of which the company chooses in accordance with the specifics and information needs of the activity.

The indicator of social capacity is calculated by the formula:

$$
E_{s}=\sum \frac{T_{s i}}{P_{s i}}
$$

where $E_{s}$ - the social capacity of the enterprise; $T_{s i}-$ the standard value of the $i$-th social indicator; $P_{s i}-$ the actual value of the $i$-th social indicator of the enterprise.

Social restrictions will be the normative values of social development indicators, the list of which the company chooses according to the specifics and information needs of the activity.

The indicator of energy capacity is determined by the formula:

$$
E_{e n}=\sum \frac{T_{e n}}{P_{e n}}
$$

where $E_{e n}$ - energy capacity of the enterprise; $T_{e n}-$ the standard value of the $i$-th energy indicator; $P_{e n}-$ the actual value of the $i$-th energy indicator of the enterprise.

Energy constraints will be the normative values of energy development indicators, the list of which the company chooses according to the specifics and information needs of the activity.

Thus, the four-level indicator of sustainable development will look like:

$$
S D=\left[E_{e c} ; E_{c} ; E_{s} ; E_{e n}\right],
$$

where $S D$ - the four-level indicator of sustainable development of the enterprise; $E_{e c}-$ economic capacity; $E_{c}-$ ecological capacity; $E_{s}$ - social capacity of the enterprise; $E_{e n}$ - energy capacity of the enterprise.

Depending on the values of economic, environmental, social and energy capacity, there are 16 scenarios for the development of the enterprise and an implementation of the tactical and strategic goals of the sustainable development of the enterprise.

As is known, the sustainable development of an enterprise provides for a balanced coexistence with the external environment. If the values of capacity indicators do not exceed 1 , then this indicates that the resources of the enterprise ecosystem are not exhausted, and therefore further harmonious development of the enterprise is possible. If the enterprise has overspending the resources of the external environment, the value of capacity indicators will exceed 1. This indicates the occurrence of contradictions between the enterprise and the ecosystem and the impossibility of their further harmonious coexistence.

It is conditionally possible to equate a value greater than one to the symbol «1», four-level indicator sustainable development of the enterprise. Then, for example, if the value of the economic, environmental, social and energy capacity is less than one, then the four-level indicator should be of the form $[0 ; 0 ; 0 ; 0]$. If the indicator of economic capacity takes a value above one, and indicators of environmental, social, and energy capacity are less than one, then the four-level indicator will look like $[1 ; 0 ; 0 ; 0]$, etc.

The proposed four-level indicator of sustainable development of the enterprise will allow to determine the feasibility and direction of the redistribution of resources between subsystems.

The value of the four-level indicator for a particular subsystem, equal to «0», indicates the presence in the ecosystem of the resource for further development. On the other hand, if the capacity indicator becomes «1», this indicates that resources for a particular subsystem have been exhausted.

The value of the indicator of the level of sustainable development is given in Table 1, where «+» marks those subsystems in which there is a reserve of resources, and «-» marks those resources that have been exhausted.

Therefore, summarizing the values of capacity indicators with subsystems of sustainable development in terms of the four-level indicator, it is possible to determine the resources by which the subsystem is in sufficient quantity, as well as the direction of their redistribution.

In particular, the resources of the economic subsystem of sustainable development of an enterprise include cash, funds invested in current and non-current assets. The environmental subsystem includes natural resources that the company uses in its activities, as well as resourcesaving technologies of the enterprise. Social resources of the enterprise include labor resources, as well as knowledge and information resources. Energy subsystems include energy resources.

The redistribution of resources requires the allocation of certain activities.

The value of the four-level indicator of sustainable development $[0 ; 0 ; 0 ; 0]$ indicates the presence of a reserve of resources for all subsystems that can be used to achieve the strategic goals of the enterprise. 
The value of the indicator of sustainable development

\begin{tabular}{|c|c|c|c|c|c|c|}
\hline \multirow{2}{*}{ No. } & \multirow{2}{*}{$\begin{array}{l}\text { The value of the four-level } \\
\text { indicator of sustainable } \\
\text { development }\end{array}$} & \multirow{2}{*}{ Characteristic of the development scenario } & \multicolumn{4}{|c|}{ Subsystems } \\
\hline & & & Economic & Ecological & Social & Energy \\
\hline 1 & $0 ; 0 ; 0 ; 0$ & $\begin{array}{l}\text { Harmonious development. There are opportunities to use the resources of the } \\
\text { external environment in perspective }\end{array}$ & + & + & + & + \\
\hline 2 & $1 ; 0 ; 0 ; 0$ & $\begin{array}{l}\text { Economic resources are exhausted. But there is a stock of environmental, } \\
\text { social and energy resources, which makes possible their further harmonious } \\
\text { development. For the development of the economic subsystem it is necessary } \\
\text { to redistribute resources }\end{array}$ & - & + & + & + \\
\hline 3 & $1 ; 1 ; 0 ; 0$ & $\begin{array}{l}\text { There is a stock of social and energy resources, which indicates the possibility } \\
\text { of harmonious development of these subsystems. The resources of the economic } \\
\text { and environmental subsystems have been exhausted, for their development it } \\
\text { is necessary to redistribute resources }\end{array}$ & - & - & + & + \\
\hline 4 & $1 ; 1 ; 1 ; 0$ & $\begin{array}{l}\text { The stock of resources is only on the energy subsystem. The resources of the } \\
\text { economic, environmental and social subsystems are exhausted; the development } \\
\text { of these subsystems requires the redistribution of resources }\end{array}$ & - & - & - & + \\
\hline 5 & $0 ; 1 ; 1 ; 1$ & $\begin{array}{l}\text { There is a stock of resources only in the economic subsystem, and resources } \\
\text { for the ecological, social and energy subsystems have been exhausted, therefore, } \\
\text { for their development it is necessary to redistribute resources }\end{array}$ & + & - & - & - \\
\hline 6 & $0 ; 0 ; 1 ; 1$ & $\begin{array}{l}\text { The presence of a stock of resources of the economic and environmental sub- } \\
\text { systems, but the exhaustion of resources of the social and energy subsystems. } \\
\text { It is possible to use the available resources of the economic and environmental } \\
\text { subsystems to improve the development of the social and energy subsystems }\end{array}$ & + & + & - & - \\
\hline 7 & $0 ; 0 ; 0 ; 1$ & $\begin{array}{l}\text { There are not enough resources for the development of the energy subsystem. } \\
\text { The resources of the economic, environmental and social subsystem can be } \\
\text { used to improve the development efficiency of the energy subsystem }\end{array}$ & + & + & + & - \\
\hline 8 & $1 ; 0 ; 0 ; 1$ & $\begin{array}{l}\text { Overuse of resources of the economic and energy subsystems. It is possible to } \\
\text { use the available resources of the ecological and social subsystems }\end{array}$ & - & + & + & - \\
\hline 9 & $1 ; 1 ; 0 ; 1$ & $\begin{array}{l}\text { Overuse of resources of the economic, environmental and energy subsystems. } \\
\text { In this case, it is advisable to use the resources of the social subsystem for } \\
\text { the development of other subsystems }\end{array}$ & - & - & + & - \\
\hline 10 & $0 ; 0 ; 1 ; 0$ & $\begin{array}{l}\text { There are not enough resources only for the development of the social subsys- } \\
\text { tem. For its development, it is possible to use the resources of the economic, } \\
\text { environmental and energy subsystems }\end{array}$ & + & + & - & + \\
\hline 11 & $0 ; 1 ; 0 ; 0$ & $\begin{array}{l}\text { Excessive resources of the ecological subsystem. For its development, it is possible } \\
\text { to use the available resources of the economic, social and energy subsystems }\end{array}$ & + & - & + & + \\
\hline 12 & $0 ; 1 ; 0 ; 1$ & $\begin{array}{l}\text { Lack of resources is typical for the ecological and energy subsystems. For } \\
\text { their development, it is possible to use the resources of the economic and } \\
\text { social subsystems }\end{array}$ & + & - & + & - \\
\hline 13 & $1 ; 0 ; 1 ; 0$ & $\begin{array}{l}\text { For the environmental and energy subsystems of the enterprise, the available } \\
\text { resources are typical, and for the economic and social - the lack of resources }\end{array}$ & - & + & - & + \\
\hline 14 & $0 ; 1 ; 1 ; 0$ & $\begin{array}{l}\text { The waste of resources of the ecological and social subsystem. At the same } \\
\text { time for their development, it is possible to use the resources of the economic } \\
\text { and energy subsystems }\end{array}$ & + & - & - & + \\
\hline 15 & $1 ; 0 ; 1 ; 1$ & Availability of resources only social subsystem & - & + & - & - \\
\hline 16 & $1 ; 1 ; 1 ; 1$ & Resources spent on all subsystems of the enterprise & - & - & - & - \\
\hline
\end{tabular}

The value of the four-level indicator of sustainable development $[1 ; 0 ; 0 ; 0]$ indicates the exhaustion of the resources of the economic subsystem and the availability of resources of the ecological, social and energy subsystems that are appropriate to use for the development of the economic subsystem. The main events will be the following:

- organizational measures to reduce waste and reduce waste in production;

- temporary reduction of environmental and social costs;

- implementation of a waste management program;

- savings from the use of resource-saving and energy-

saving technologies;
- it is possible to receive additional income from the use of energy-saving technologies (solar panels);

- obtaining additional economic effect from the benefits of the social subsystem of sustainable development: the growth of labor productivity, high qualification of workers, and the inclusion of workers in the overall strategy of the company;

- obtaining an additional economic effect from the advantages of the ecological subsystem: the company's image, ecological products.

If the resources of the economic and ecological subsystems are exhausted, then the four-level indicator of sustainable development becomes $[1 ; 1 ; 0 ; 0]$. At the same 
time, resources must be redistributed across the social and energy subsystems in the economic and environmental. To do this, it is possible to apply the following measures:

- organizational measures to reduce waste and reduce waste in production;

- temporary reduction in social spending;

- implementation of a waste management program;

- savings from the use of energy-saving technologies;

- it is possible to receive additional income from the use of energy-saving technologies (solar panels);

- obtaining an additional economic effect from the advantages of the social subsystem of sustainable development: the growth of labor productivity, highly skilled workers;

- promoting the sustainable development of the environmental subsystem by increasing the environmental awareness of workers.

If the resources of the economic, environmental and social subsystems are exhausted, but there is a supply of resources for the energy subsystem, then the four-level indicator becomes $[1 ; 1 ; 1 ; 0]$. At the same time, the resources of the energy subsystem must be used for the development of other subsystems. The events will be as follows:

- reduction of environmental, social and energy costs;

- savings from the use of energy-saving technologies;

- it is possible to receive additional income from the use of energy-saving technologies (solar panels);

- organizational measures to reduce waste and rejects;

- increase productivity and reduce employee turnover;

- inclusion of workers in the overall strategy of the company and increase the environmental awareness of workers;

- implementation of a more rational and effective system of motivation and remuneration in order to optimize labor benefits.

The value of the four-level indicator of sustainable development $[0 ; 1 ; 1 ; 1]$ indicates the existing stock of resources of the economic subsystem, but the exhaustion of resources of the ecological, social and energy subsystems. At the same time, the resources of the economic subsystem of an enterprise should be used to improve the development efficiency of other subsystems. The main events will be as follows:

- implementation of resource-saving technologies and the programs for the use of waste;

- development and implementation of environmental products;

- implementation of a more efficient system of motivation and remuneration in order to increase labor productivity and reduce staff turnover;

- training and staff development;

- inclusion of workers in the overall strategy of the company and increasing their environmental awareness;

- implementation of energy-saving technologies;

- organizational measures to reduce waste and waste production.

If the four-level indicator of sustainable development becomes $[0 ; 0 ; 1 ; 1]$, this indicates the presence of a stock of resources of the economic and environmental subsystems, but the exhaustion of resources of the social and energy subsystems. Thus, an enterprise can use the available resources of the economic and environmental subsystems to increase the development efficiency of the social and energy subsystems, namely:

- implementation of a more efficient system of motivation and remuneration in order to increase labor productivity and reduce staff turnover;

- training and staff development;

- inclusion of workers in the overall strategy of the company and increasing their environmental awareness;

- implementation of energy-saving technologies;

- organizational measures to reduce waste and waste production.

If there are not enough resources only for the developed energy subsystem, then the four-level indicator of sustainable development becomes $[0 ; 0 ; 0 ; 1]$. The resources of the economic, environmental and social subsystems can be used to improve the development of the energy subsystem. The main activities at the same time are an implementation of energy-saving technologies.

If the four-level indicator of sustainable development takes on the value $[1 ; 0 ; 0 ; 1]$, then this indicates a waste of resources of the economic and energy subsystems. Thus, an enterprise can use the available resources of the ecological and social subsystems, namely:

- reduction of environmental and social costs;

- organizational measures to reduce waste and rejects;

- organizational measures to reduce energy costs;

- obtaining additional economic effect from the benefits

of the social subsystem of sustainable development: the growth of labor productivity, high qualification of workers, and the inclusion of workers in the overall strategy of the company;

- obtaining an additional economic effect from the advantages of the ecological subsystem: the company's image, ecological products.

The value of the four-level indicator $[1 ; 1 ; 0 ; 1]$ indicates the overrun of the resources of the economic, environmental and energy subsystems. In this case, it is advisable to use the resources of the social subsystem for the development of other subsystems. To do this, it is possible to apply the following measures:

- organizational measures to reduce waste and reduce waste in production;

- temporary reduction in social spending;

- obtaining an additional economic effect from the benefits of the social subsystem of sustainable development: an increase in labor productivity, high qualification of workers, and the inclusion of workers in the overall strategy of the company.

In case there are not enough resources only for the development of the social subsystem, then the value of the four-level indicator of sustainable development is $[0 ; 0 ; 1 ; 0]$. For the development of the social subsystem, it is possible to use the resources of other subsystems of sustainable development, including through the following measures:

- savings from the use of energy-saving technologies;

- it is possible to receive additional income from the use of energy-saving technologies (solar panels);

- implementation of a more efficient system of motivation and remuneration in order to increase labor productivity and reduce staff turnover;

- training and staff development;

- inclusion of workers in the overall strategy of the company and increase their environmental awareness. The value of the four-level indicator of sustainable 
development $[0 ; 1 ; 0 ; 0]$ indicates a lack of resources of the ecological subsystem when there is a supply of resources of other subsystems. It is possible to apply such measures as:

- implementation of resource-saving technologies and the programs for the use of waste;

- development and implementation of environmental products;

- inclusion of workers in the overall strategy of the company and increasing their environmental awareness; - organizational measures to reduce waste and waste production.

If the lack of resources is typical for the environmental and energy subsystems, then the four-level indicator sustainable development takes on the value $[0 ; 1 ; 0 ; 1]$, and the main activities will be:

- implementation of resource-saving technologies and the programs for the use of waste;

- development and implementation of environmental products;

- inclusion of workers in the overall strategy of the company and increasing their environmental awareness;

- implementation of energy-saving technologies;

- organizational measures to reduce waste and waste production.

If the ecological and energy subsystems of the enterprise are characterized by an existing supply of resources, and for the economic and social, there is a shortage of resources, then the four-level indicator of sustainable development takes on significance $[1 ; 0 ; 1 ; 0]$. It is advisable to apply the following measures:

- organizational measures to reduce waste and reduce waste in production;

- temporary reduction of environmental costs;

- implementation of a waste management program;

- savings from the use of resource-saving and energysaving technologies;

- it is possible to receive additional income from the use of energy-saving technologies (solar panels);

- obtaining an additional economic effect from the advantages of the ecological subsystem: the company's image, ecological products;

- implementation of a more efficient system of motivation and remuneration in order to increase labor productivity and reduce staff turnover;

- training and staff development;

- inclusion of workers in the overall strategy of the company and increase their environmental awareness. The value of the indicator $[0 ; 1 ; 1 ; 0]$ indicates an overspending of resources of the ecological and social subsystem. At the same time for their development, it is possible to use the resources of the economic and energy subsystems of the enterprise, so the following measures will be applied:

- implementation of resource-saving technologies and the programs for the use of waste;

- development and implementation of environmental products;

- implementation of a more efficient system of motivation and remuneration in order to increase labor productivity and reduce staff turnover;

- training and staff development;

- inclusion of workers in the overall strategy of the company and increasing their environmental awareness;
- organizational measures to reduce waste and waste production.

The value of the four-level indicator of sustainable development $[1 ; 0 ; 1 ; 1]$ indicates the presence of a stock of resources only of the social subsystem. In this case, the main measures will be as follows:

- organizational measures to reduce waste and reduce waste in production;

- temporary reduction in social spending;

- implementation of a waste management program;

- inclusion of workers in the overall strategy of the company and increase their environmental awareness.

If the indicator becomes $[1 ; 1 ; 1 ; 1]$, then resources overspending in all subsystems of the enterprise. In this case, the company lacks the ability to attract financial, labor, environmental and energy resources for further development. Therefore, the enterprise needs to apply organizational measures to reduce energy and resource costs, inefficient use of working time, slow workers to the overall strategy of the enterprise, develop the environmental awareness of workers, look for reserves of economic growth.

\section{SWOT analysis of research results}

Strengths. The strengths lie in the fact that the developed four-level indicator of sustainable development of an enterprise allows to assess the ability of an enterprise to develop successfully in harmony with the ecosystem.

The four-level indicator of sustainable development and based on its significance, sustainable development scenarios are universal for enterprises of any industry.

This indicator demonstrates the development prospects of each of the subsystems of the enterprise in accordance with which it is possible to build scenarios of sustainable development of the enterprise. Depending on certain scenarios, it is possible to determine the subsystems that lack the external environment resources for development, as well as the subsystems that have a reserve of resources, allows for their effective redistribution.

Weaknesses. The main weakness of this method is the difficulty of establishing standard values for some indicators, which are composite indicators of capacity. The correctness of the redistribution of resources between the subsystems depends on how correctly the standards are determined.

Opportunities. The scenarios are formed on the basis of the four-level indicator of sustainable development that makes it possible in the future to develop an effective system of measures for the redistribution of resources between subsystems.

Threats. The main threat to the use of indicators of sustainable development is that harmonious coexistence with the external environment is not an exhaustive condition for the crisis-free development of an enterprise. Failure to take this aspect into account can lead to errors in the reallocation of resources.

\section{Conclusions}

1. As a research result of methodological approaches to assessing the level of sustainable development of an enterprise, taking into account the interaction with the external environment, a four-level indicator of sustainable development of an enterprise has been built, including indicators of economic, environmental, social and energy 
capacity. This makes it possible to determine the prospects for the development of an enterprise in harmony with its ecosystem.

2. In accordance with the values of the four-level indicator, there are reasonable scenarios for the sustainable development of an enterprise, demonstrating ways of redistributing resources between subsystems.

\section{References}

1. Searcy C. Measuring Enterprise Sustainability // Business Strategy and the Environment. 2014. Vol. 25, Issue 2. P. 120-133. doi: http://doi.org/10.1002/bse.1861

2. Zenya A., Nystad O. Assessing Corporate Sustainability with the Enterprise Sustainability Evaluation Tool (E-SET) // Sustainability. 2018. Vol. 10, Issue 12. P. 4661. doi: http://doi.org/ $10.3390 / \mathrm{su} 10124661$

3. Hellmeister A., Richins H. Green to Gold: Beneficial Impacts of Sustainability Certification and Practice on Tour Enterprise Performance // Sustainability. 2019. Vol. 11, Issue 3. P. 709. doi: http://doi.org/10.3390/su11030709

4. Shchetkin B. N. Analysis of Enterprise Sustainability and Control of Efficiency of Cattle-Breeding Enterprise Functioning // Mediterranean Journal of Social Sciences. 2015. doi: http:// doi.org/10.5901/mjss.2015.v6n3s6p101

5. Kucharčíková A., Mičiak M., Hitka M. Evaluating the Effectiveness of Investment in Human Capital in E-Business Enterprise in the Context of Sustainability // Sustainability. 2018. Vol. 10, Issue 9. P. 3211. doi: http://doi.org/10.3390/su10093211

6. Sustainable Enterprise Excellence: Attribute-Based Assessment Protocol / Hussain T., Edgeman R., Eskildsen J., Shoukry A.,
Gani S. // Sustainability. 2018. Vol. 10, Issue 11. P. 4097. doi: http://doi.org/10.3390/su10114097

7. Trica C., Banacu C., Busu M. Environmental Factors and Sustainability of the Circular Economy Model at the European Union Level // Sustainability. 2019. Vol. 11, Issue 4. P. 1114. doi: http://doi.org/10.3390/su11041114

8. Illés M. Enterprise Models in Terms of Sustainability // Theory, Methodology, Practice. 2016. Vol. 12, Issue 2. doi: http://doi.org/ 10.18096/tmp.2016.02.05

9. Zhilinska L. O. Management of the development of machinebuilding enterprises for a strategic perspective: $\mathrm{PhD}$ Doctor of Economic Sciences theses. Mariupol, 2016. 436 p.

10. Lyaskovets $\mathrm{O}$. V. Mechanism of economic security development of mechanical engineering enterprises: $\mathrm{PhD}$ theses. Zaporizhia, 2018. 791 p.

11. Murashko I. S. Bionomic Approach to Sustainable Enterprise Development // Bulletin of the Zaporizhzhya National University. Economic Sciences. 2017. Vol. 4. P. 43-49.

12. Goncharenko G. E., Sovgir S. V. A dictionary-directory of modern environmental and environmental terms. Kyiv: Science World, 2010. 67 p.

Katkova Natalia, PhD, Associate Professor, Department of Accounting and Economic Analysis, Admiral Makarov National University of Shipbuilding, Mykolaiv, Ukraine, ORCID: http://orcid.org/00000002-6199-4841, e-mail: nataliavkatkova@gmail.com

Murashko Irina, Lecturer, Department of Economics and Management, Danube Branch of Interregional Human Resource Management Academy, Izmail, Odessa region, Ukraine, ORCID: http:// orcid.org/0000-0002-4635-6921, e-mail: murashkoirene@gmail.com 